\title{
EFFECTS OF SEAWEED SUPPLEMENTATION TO FATTENING FRIESIAN STEERS RATIONS ON: \\ 2- BLOOD PARAMETERS, PERFORMANCE AND FEED EFFICIENCY
}

Ead, H. M. E. ${ }^{1}$ and Eman H. M. Maklad ${ }^{2}$

1- Animal Production Res. Inst., Agric. Res. Center, Dokki, Giza, Egypt.

2-Animal Production Dept., Fac. Agric., Mansoura University, Egypt.

\section{ABSTRACT}

Twelve male Friesian steers with average body weight $269_{ \pm} 9 \mathrm{~kg}$ and 15 month of age were used in this study. Steers were distributed into three groups similar in number. The experimental rations were formulated as follows: ration 1 (R1) $81.8 \%$ concentrate feed mixture $(\mathrm{CFM})+18.2 \%$ clover hay $(\mathrm{CH})($ control), ration 2 (R2): $81.55 \% \mathrm{CFM}+18.05 \% \mathrm{CH}+0.40 \%$ seaweed $(\mathrm{S})$ and ration 3 (R3): $81.23 \%$ $\mathrm{CFM}+17.87 \% \mathrm{CH}+0.90 \% \mathrm{~S}$.

The results obtained showed that the mean values of blood parameters were not significantly affected by the feeding on R1 or R2 or R3. The concentration of urea-N in blood was decreased with feeding on R2 and R3 than feeding on R1.

The average daily gains were $0.81,1.00$ and $0.83 \mathrm{~kg} / \mathrm{d}$ for steers fed on R1, $\mathrm{R} 2$ and R3, respectively. The production efficiency was higher when feeding on R2 (24.04\%) than feeding on R1 or R3 (20.97 and $19.17 \%$, respectively), and the economic efficiency, was higher when feeding on R2 $(25.39 \%)$ than feeding on R1 or R3 (13.3 and $3.94 \%$, respectively).

In general, the results indicated that feeding ration at a level $81.55 \% \mathrm{CFM}+$ $18.05 \% \mathrm{CH}+0.4 \% \mathrm{~S}$ for fattening Friesian steers was economically improved animal performance compared with the other two rations.

Keywords: Friesian steers, seaweed, daily gain and economic efficiency.

\section{INTRODUCTION}

Beef production is a large and important segment of animal production and one of the largest industries in the world. Cattle usually weight 270 to $310 \mathrm{~kg}$ before they are placed on high grains (high energy) ration. This diet is fed until slaughter weight is achieved. An animal that is gaining weight at a moderate rate needs about $1.5 \%$ of their body weight in concentrates per day.

Rapidly growing cattle, such as calves can be safely fed up to 2.0 to $2.25 \%$ of their weight in concentrates and feeding roughage at least 1.8 to $2.2 \mathrm{~kg}$ of hay daily. However, neither should be fed at over $20 \%$ of the diet (Schreder, 2002). Finishing cattle in the terminal stage of fattening are often fed diets with low concentrations of roughage to maintain performance and achieve targeted back fat finish and marbling that desired by beef industry. High energy fattening rations have $70 \%$ TDN and 9 to $15 \%$ CF (Mandell et al., 2001).

Buffer supplementation of high concentrate diets has been shown to improve or stabilize food intake and increase animal performance in some studies (Zinn, 1991), but not in others (Ghorbani et al., 1989). 
Aga et al. (2000) used a calcified seaweed as a buffer in continuous culture of rumen content. The chemical composition of an ordinary seaweed from Ascophyllum nodosum, immediately characterized the material as of low energy content. According to the analytical data, the value of seaweed meal must primarily be sought in its content of vitamins and minerals, among which $\beta$-carotene, tocopherols, some B-vitamins, iodine, zinc and potassium are the more important (Scott, 1990).

The most frequently reported benefits associated with inclusion of Ascophyllum nodosum in animal diet include increased weight gain and improved carcass quality. Slaughter yield improves with age, for a given carcass weight, animals at high growth rate, receiving more balanced feed and generally have a better carcass yield (Lebas and Colin, 1992).

The objective of this study was to evaluate the effect of seaweed supplementation to fattening steers rations on some blood constituents, growth performance and economic efficiency.

\section{MATERIALS AND METHODS}

This study was conducted at El-Karada Animal Production Research Station, Animal Production Research Institute, Agricultural Research Center, Ministry of Agriculture in Egypt and Department of Animal Production, Fac. of Agric., Mansoura University.

\section{Experimental animals:}

Twelve male Friesian steers with average live body weight $269_{ \pm} 9 \mathrm{~kg}$ and 15 month of age were distributed into three similar groups (Four for each). The

Three experimental rations were formulated as follows:

R1: ration 1: $81.8 \%$ concentrate feed mixture (CFM) $+18.2 \%$ clover hay

(CH) (as a control ration).

R 2: ration $2: 81.55 \% \mathrm{CFM}+18.05 \% \mathrm{CH}+0.40 \%$ seaweed (S)

R 3: ration 3: $81.23 \% \mathrm{CFM}+17.87 \% \mathrm{CH}+0.90 \% \mathrm{~S}$.

The CP concentration of tested rations were ranged from 16 to $17 \%$ according to Hunter et al (1999). Steers were individually fed the experimental rations to cover the requirements of fattening steers and were adjusted monthly according to their body weight changes. Experimental period extended for five months.

The concentrate feed mixture (CFM) used contained $44 \%$ yellow corn , $23 \%$ soybean meal (44\% protein), $14 \%$ wheat bran, $11.5 \%$ rice bran , $4.5 \%$ molasses, $2 \%$, limestone and $1 \%$ salt. The clover hay was made from the $3^{\text {rd }}$ cut of Egyptian clover.

The supplement seaweed meal as from Ascophyllum nodosum manufactured by Acadian Sea plants Limited, Canada. The approximate label analysis showed that it contains of protein, fiber, carbohydrates, vitamins and minerals.

\section{Management of feeding:}

The intake of tested ration by animals was fixed and calculated as the percentage of roughage to concentrate ratio to satisfy their maintenance and production requirements (Ghoneim, 1967). 
The CFM fed with or without seaweed was offered to steers at morning. While, clover hay $(\mathrm{CH})$ given after consumption of the concentrate. Drinking fresh and clean water was available at all times.

Weighing procedure:

Animals were weighed in the morning before drinking and feeding at the beginning of the trial and monthly thereafter to the nearest $\mathrm{kg}$ for each animal.

\section{Chemical analysis:}

Blood samples were taken from each animal individually during the digestion trials of the tested rations. These samples were taken at $3 \mathrm{hrs}$ postfeeding from jugular vein. Blood samples were immediately separated by centrifugation at $4000 \mathrm{rpm}$ for 10 minutes. The serum samples were stored at $\left(-20^{\circ} \mathrm{C}\right)$ until analysis were done. The analysis included total protein (Gornall et al., 1949); albumin (Hill and Wells, 1983); globulin (calculated by differences between the total protein and albumin concentrations); urea (Freidman et al., 1980); creatinine (Ullmann, 1976); Glucose (Teuscher and Richterich, 1971); GOT and GPT (Reitman and Frankel, 1957).

\section{Production efficiency :}

The ME can be concerted to a NEm requirement with an efficiency of 0.576 (NRC, 1996) and NEp will equal (ME-NEm).

The retained energy $(\mathrm{RE}, \mathrm{Mcal} / \mathrm{d})=\left(\right.$ live weight $\left.{ }^{0.2955} \times 0.544\right) \times(\mathrm{ADG})^{1.262}$ Where ADG is in kilograms (Overton, 1999).

Production efficiency $=R E / N E_{p} \times 100$

Economic efficiency :

Economic efficiency was calculated according to the following formula:

Economic efficiency $=\underline{\text { (Price of daily gain }- \text { Daily feed cost })}$

\section{Statistical analysis:.}

Daily feed cost

The statistical analysis was performed using the least squares method described by Likelihood programmer of SAS (1994). The obtained data for performance and blood parameters were subjected to one way analysis of variance according to the following model:

$Y_{i j}=\mu+T_{i}+e_{i j}$

Where:

$$
\begin{aligned}
& Y i j=\text { Observation of the tested factor } \\
& \mu=\text { Overall mean } \\
& T_{i}=\text { Treatment effect } \\
& \mathrm{e}_{\mathrm{ij}}=\text { Error }
\end{aligned}
$$

The differences among means were carried out according to Duncan's New Multiple Range Test (Duncan, 1955).

\section{RESULTS AND DISCUSSION}

Concerning blood metabolism, data in Table (1) shows that the values were in the normal range as described by Mohamed and Selim (1999), but without significant effect. 
The concentration of urea- $\mathrm{N}$ in blood was decreased with feeding on $\mathrm{R} 2$ and R3 than feeding on R1. The concentration is affected not only by dietary intake of digestible crude protein in the rumen but also by balance between energy and protein in the diet (Hoffman and Steinhofel, 1990).

Table (2) shows the effect of feeding tested rations on average body weight (ABW) and average daily gain (ADG). There were no significant effect on the average body weight appeared among tested group. However, the $(A D G)$ was higher $(p<0.05)$ from 17-18 month when animals were fed on R2 or R3 than R1, and then increased $(p<0.05)$ from $19-20$ month when fed on $\mathrm{R} 2$ than $\mathrm{R} 1$ or $\mathrm{R} 3$. The average daily gains for whole experimental period were $0.81,1.00$ and $0.83 \mathrm{~kg} /$ day for $\mathrm{R} 1, \mathrm{R} 2$ and $\mathrm{R} 3$, respectively.

Table (1): Effect of experimental rations on some blood parameters.

\begin{tabular}{|c|c|c|c|c|c|}
\hline \multirow{2}{*}{ Item } & \multicolumn{5}{|c|}{ Experimental rations } \\
\hline & Ration 1 & Ration 2 & Ration 3 & +SEM & $p$ \\
\hline Total protein $\mathrm{g} / 100 \mathrm{ml}$ & 6.49 & 6.45 & 5.63 & 0.300 & 0.1523 \\
\hline Albumin $\mathrm{g} / 100 \mathrm{ml}$ & 4.93 & 5.42 & 4.93 & 0.293 & 0.4399 \\
\hline Globulin $\mathrm{g} / 100 \mathrm{ml}$ & 1.56 & 1.03 & 0.70 & 0.259 & 0.1363 \\
\hline Creatinine $\mathrm{mg} / \mathbf{1 0 0} \mathrm{ml}$ & 0.18 & 0.31 & 0.26 & 0.479 & 0.2484 \\
\hline Urea-n mg/100 ml & 23.76 & 20.53 & 20.95 & 1.873 & 0.4623 \\
\hline GOT IU/L & 61.30 & 60.30 & 58.60 & 5.385 & 0.9399 \\
\hline GPT IU/L & 10.00 & 12.70 & 12.60 & 1.586 & 0.4410 \\
\hline Glucose (mg/100 ml) & 64.64 & 54.98 & 53.63 & 3.953 & 0.1805 \\
\hline
\end{tabular}

Table (2):Effect of feeding tested ration on average body weight $(\mathrm{kg})$ and daily gain $(\mathbf{k g})$.

\begin{tabular}{|c|c|c|c|c|c|c|c|c|c|c|}
\hline \multirow{2}{*}{ Item } & \multicolumn{5}{|c|}{ ABW } & \multicolumn{5}{|c|}{ ADG } \\
\hline & R1 & R2 & R3 & \pm SEM & $p$ & R1 & $\mathbf{R 2}$ & R3 & +SEM & $p$ \\
\hline $\begin{array}{|ll|}\begin{array}{l}\text { Initial } \\
\text { month }\end{array} & \text { BW } \quad 15 \\
\end{array}$ & 261 & 271 & 274 & 9.33 & 0.6051 & - & - & - & - & - \\
\hline 15-16 month & 296 & 310 & 310 & 11.70 & 0.6405 & 1.17 & 1.30 & 1.19 & 0.391 & 0.643 \\
\hline 16-17 month & 311 & 322 & 322 & 11.28 & 0.7410 & 0.50 & 0.40 & 0.40 & 0.066 & 0.494 \\
\hline 17-18 month & 331 & 368 & 363 & 12.54 & 0.1316 & $0.67^{\mathrm{b}}$ & $1.53^{\mathrm{a}}$ & $1.38^{\mathrm{a}}$ & 0.192 & 0.024 \\
\hline 18-19 month & 363 & 393 & 382 & 15.22 & 0.3910 & 1.05 & 0.84 & 0.63 & 0.150 & 0.201 \\
\hline $\begin{array}{l}\text { Final BW 19-20 } \\
\text { month }\end{array}$ & 383 & 421 & 398 & 15.90 & 0.2929 & $0.70^{\mathrm{b}}$ & $0.92^{\mathrm{a}}$ & $0.53^{b}$ & 0.066 & 0.008 \\
\hline Mean15-20month & - & - & - & - & - & 0.81 & 1.00 & 0.83 & - & - \\
\hline
\end{tabular}

Table (3) shows that there was no significant effect of DMI between the treatments however, the DMI was increased when fed on R3 than R1 or R2, while the DMI increase $(p<0.05)$ when feeding on R2 than R1, but the production efficiency was higher with feeding on R2 ((24.04\%) than feeding on R1 or R3 (20.97 and $19.17 \%$, respectively).

The price of the total fresh feed intake/day was higher when feeding on R3 than feeding on R1 or R2 and the price of R2 was higher than R1 as shown in Table (4). Feeding on R2 was more economic efficiency (25.39\%) than feeding on R1 or R3 (13.35 and 3.94\%, respectively). 
Table (3): Production efficiency of growing steers fed the experimental rations.

\begin{tabular}{|l|c|c|c|c|c|}
\hline Item & $\mathbf{R 1}$ & $\mathbf{R 2}$ & $\mathbf{R 3}$ & $\mathbf{+ S E}$ & $\boldsymbol{P}$ \\
\hline DMI (kg/d) & 9.99 & 10.03 & 10.07 & 0.000 & 0.0001 \\
\hline ME (Mcal/kg) & 3.02 & 3.04 & 3.09 & 0.5746 & 0.5504 \\
\hline ME (Mcal/d) & 30.20 & 30.49 & 31.12 & 0.5746 & 0.5504 \\
\hline NEp (Mcal/d) & 12.81 & 12.93 & 13.19 & 0.2436 & 0.5507 \\
\hline Live weight (kg) & 393 & 396 & 388 & 12.801 & 0.8999 \\
\hline ADG (kg/d) & 0.87 & 0.98 & 0.83 & 0.0661 & 0.3363 \\
\hline Retained energy Mcal/d & 2.68 & 3.11 & 2.54 & 0.2767 & 0.3795 \\
\hline Production efficiency & 20.97 & 24.04 & 19.17 & 1.969 & 0.2841 \\
\hline
\end{tabular}

Table (4): Economic efficiency of steers fed the experimental rations.

\begin{tabular}{|l|c|c|c|}
\hline \multicolumn{1}{|c|}{ Item } & R1 & R 2 & R 3 \\
\hline Price / kg fresh (LE) & 15.35 & 15.63 & 15.97 \\
\hline ADG kg/d & 0.87 & 0.98 & 0.83 \\
\hline Price of daily gain (LE) & 17.4 & 19.6 & 16.6 \\
\hline Profit (LE) & 2.05 & 3.97 & 0.63 \\
\hline Economic efficiency \% & 13.35 & 25.39 & 3.94 \\
\hline
\end{tabular}

Market price pt./kg fresh of: concentrate feed mixture= 170; clover hay=80; seaweed $=700$; $\mathrm{kg}$ body weight gain $=2000$.

Hersom (2005) reported that, accurate supply of nutrients to cattle can have several positive outcomes. Providing the required nutrients can increase the production potential, reduced feed cost and improve nutrient utilization thereby also reducing nutrient waste and decreasing environmental concerns.

It could be concluded from the presented results that feeding on $82 \%$ concentrate feed mixture and $18 \%$ clover hay, which contains $0.4 \%$ seaweed of the total ration intake for fattening Friesian steers, successfully and economically improved animal performance, compared with ration without seaweed or with $0.9 \%$ seaweed.

\section{REFERENCES}

Aga, L. M.; Koski, R. J. and Stern, M. D. (2000). Effect of buffers on pH and microbial metabolism in continuous culture of rumen contents. $25^{\text {th }}$ Conference on rumen function, Chicago, Illinois.

Duncan, D.B. (1955). Multiple Range and Multiple F Test. Biometrics, 11:10.

Freidman, R. B.; Anderson R. E.; Entine S. M. and Hinshberg S. B. (1980). Effects of disease on clinical laboratory tests. Clin. Chem.; 26: 26D.

Ghoneim, A. (1967). Animal Nutrition, Principles and Feeding-stuffs. $2^{\text {nd }}$ Edt. Anglo. Egyptian Library, University. (Arabic Text Book).

Ghorbani, G. R.; Jackson, J. A. and Hemken, R. W. (1989). Effect of sodium bicarbonate and sodium sesquicarbonate on animal performance, ruminal metabolism and acid - base status. J. Dairy Sci. $72: 2039$.

Gornall, A. C.; Bard, W. and David M. M. (1949). Determination of total serum protein. J. Biol. Chem., 177: 751.

Hersom, H. (2005). Phase-feeding the beef herd for improved feed utilization. Florida Ruminant Nutrition Symposium. 
Hill, P. G. and Wells T. N. (1983). Reduction of reaction differences between human mercaptalbumin and human nonmercaptalbumin measured by the bromocresol purple method. Ann. Clin Biochem., 20: 264.

Hoffman, M. and Steinhofel, O. (1990). Possibilities and restriction in using milk urea concentrations as markers of energy and protein balance . Mh. Vet. Med. 45: 223.

Hunter, R. D.; Drouillard, J. S. and Titgemeyer, E. C. (1999). Effect of level of non-enzymatically browned soybean meal in limited fed, grain sorghum diets for growing fibers. Kansas State University Agricultural Experiment Station and Cooperative Extension Service.

Lebas, F. and Colin, M. (1992). World rabbit production and research: Situation in 1992. Fifth World Rabbit Congress, Vol. A, p. 29.

Mandell, I.B.;Campbell, C. P.; Buchanan-Smith, J. G. and Wilton, J. W. (2001). Effects of source and level of dietary roughage on growth performance and carcass quality in yearling calves. Department of Animal and Poultry Science, University of Guelph, Guelph, Ontario.

Mohamed, H. A. and Selim, H. M. (1999). Hand book of Veterinary Internal Medicine. Department of Animal Medicine, Faculty of Veterinary Medicine. Zagazig Univ.

NRC (National Research Council) (1996). Nutrient Requirements of beef Cattle $\left(7^{\text {th }}\right.$ ed.) National Academy Press, Washington, DC.

Overton, T. (1999). "Research Feature" Total Dairy Nutrition, Vol, 1, No, 2 April (1999).

Reitman, A. and Frankel, S. (1957). A colorimetric method of determination of s.GOT and s.GPT. American J. of Clinical Pathology, 28: 56.

SAS (1994). SAS / STAT R User's Guide : Statistics. Ver. 6.04, Fourth Edition SAS Institute Inc, Cary, NC.

Schreder, P. (2002). Feeding \& Riparian the show steer. OUS \& Riparian, Linn / Benton / Lan Countries No. L \& R.

Scott, C. (1990). Kelp Help : Livestock thrive on seaweed. Elphin, Lanark Country, Eastern Ontario, Canada.

Teuscher, A. and Richterich, R. (1971). Schweiz. Med. Woschr. 101: 345.

Ullmann, K. (1976).Bonitz. Med. Labor., 29:137 .

Zinn, R. A. (1991). Comparative feeding value of steam - flaked corn and sorghum in finishing diets supplemented with or without sodium bicarbonate. J. Anim. Sci. $69: 905$. 
تـأثير إضـافة الطحالب البحريـة لعلائق تسمين عجـول الفريزيـان على : 2- الأداء الإنتاجى فى المرحلة النهائية

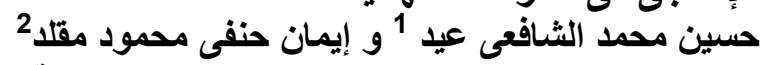

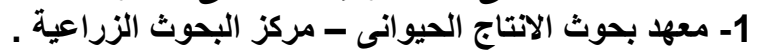

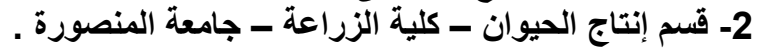

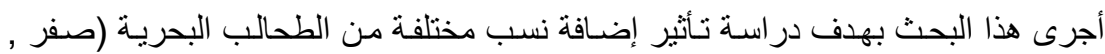

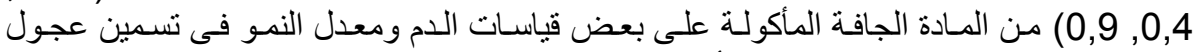

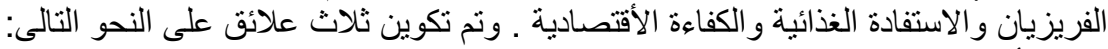

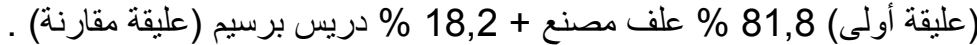

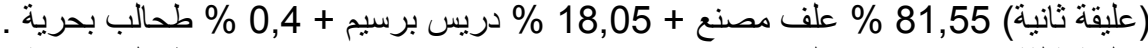

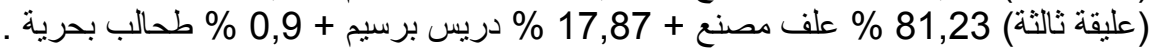

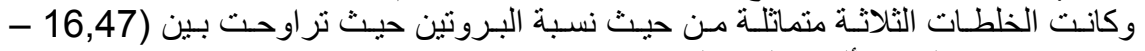

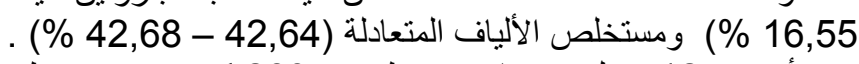

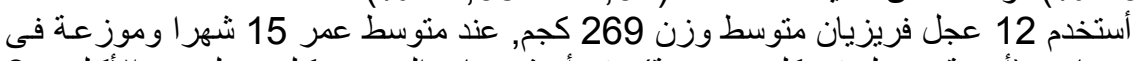

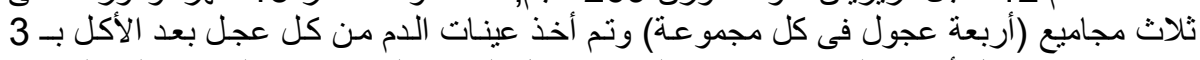

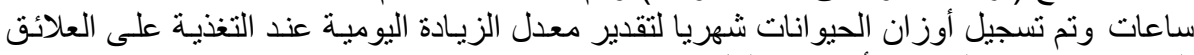

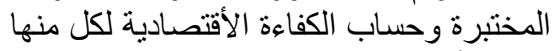
وكانت أهم النتائج المتحصل عليها كما يلى :

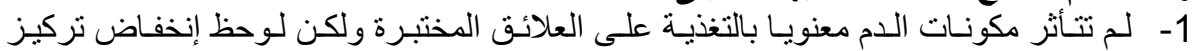

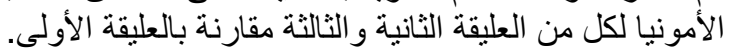

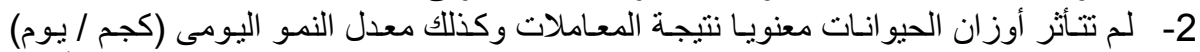
خـلال فترة التجربـة (

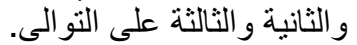

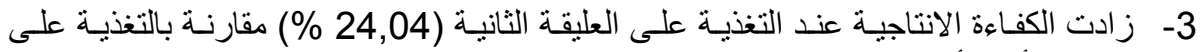

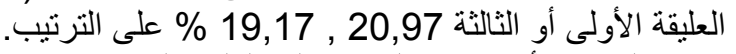

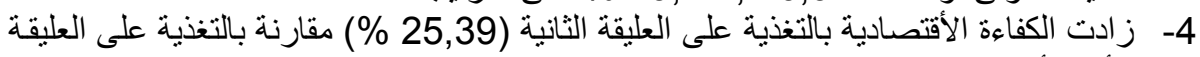

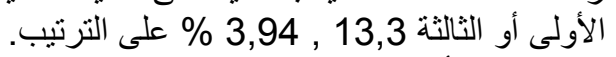

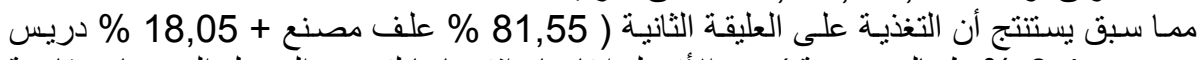
برسيم + 0,4 \% طحالب بحرية ) هى الأفضل إنتاجيا و إقتصاديا لتسمين العجول الفئن الفريزيان مقارنة

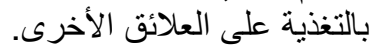

كلية الزراعة - جامعة المنصورة

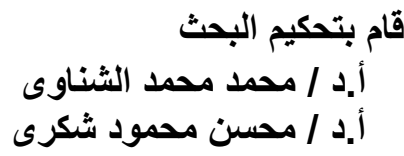
اكاديمية البحث العلمى 